\title{
Interleukin-2 Receptor Subunit Alpha
}

National Cancer Institute

\section{Source}

National Cancer Institute. Interleukin-2 Receptor Subunit Alpha. NCI Thesaurus. Code C17073.

Interleukin-2 receptor subunit alpha (272 aa, $\sim 31 \mathrm{kDa}$ ) is encoded by the human IL2RA gene. This protein plays a role in interleukin-2-dependent signaling. 